CREATING A CLASS 



\section{REATING A}

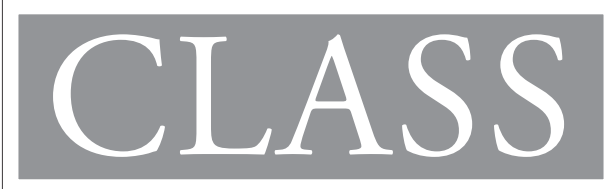

College Admissions and the Education of Elites

\section{Mitchell L. Stevens}

Harvard University Press

Cambridge, Massachusetts

London, England 
Copyright (C) 2007 by the President and Fellows of Harvard College All rights reserved

Printed in the United States of America

First Harvard University Press paperback edition, 2009

\section{Library of Congress Cataloging-in-Publication Data}

Stevens, Mitchell L.

Creating a class : college admissions and the education of elites /

Mitchell L. Stevens

$$
\text { p. } \mathrm{cm} \text {. }
$$

Includes bibliographical references and index.

ISBN-13: 978-0-674-02673-5 (cloth: alk. paper)

ISBN-13: 978-0-674-03494-5 (pbk.)

1. Universities and colleges-United States-Admission.

2. Education, Higher-United States.

3. Elite (Social sciences)—United States. I. Title.

LB2351.2.S755 2007

$371.1^{\prime} 610973-\mathrm{dc} 22 \quad 2007010897$

Designed by Gwen Nefsky Frankfeldt 
For the College 
